\title{
Pengaruh Rekrutmen Dan Seleksi Terhadap Kinerja Karyawan Pada PT.
} Boga Lestari Sentosa

\author{
Reni Hindriari \\ Dosen Fakultas Ekonomi, Universitas Pamulang \\ Email : reni.hindriari@gmail.com
}

\begin{abstract}
ABSTRAK
Dalam suatu organisasi atau perusahaan untuk menentukan posisi orang yang tepat di dalam mengisi suatu jabatan, jika jabatan tersebut tidak dibuat dalam suatu batasan yang jelas serta menyangkut ruang lingkup jabatan dan spesifikasi sipemegang jabatan. Yang bisa dijadikan dasar untuk melakukan rekrutmen dan seleksi. Dengan adanya rekrutmen dan seleksi, maka calon karyawan yang diterima sudah sesuai dengan kriteria yang diperlukan dalam suatu organisasi. Tujuan dari penelitian ini adalah (1) untuk mengetahui pengaruh rekrutmen terhadap kinerja karyawan secara parsial, (2) untuk mengetahui pengaruh seleksi terhadap kinerja karyawan secara parsial dan (3) untuk mengetahui pengaruh rekrutmen dan seleksi terhadap kinerja karyawan secara simultan.

Sifat penelitian ini bersifat deskriptif kuantitatif, yaitu menggambarkan atau mendeskripsikan pengaruh hubungan sebab dan akibat dari penelitian ini. Pengumpulan data yang digunakan dalam penelitian ini antara lain observasi, penyebaran kuesioner dan wawancara. Metode yang telah digunakan dalam penelitian ini adalah deskriptif (kualitatif) dan verifikatif (kuantitatif) serta pengolahan data dengan menggunakan Statistical Package for Social Science (SPSS). Sampel dari penelitian ini adalah 69 karyawan.

Hasil dari penelitian ini menunjukkan bahwa rekrutmen berpengaruh positif dan signifikan terhadap kinerja karyawan secara parsial sebesar $t_{\text {hitung }}>t_{\text {tabel }}(5,098>1,996)$ pada taraf signifikansi $0,000<0,05$, artinya $\mathrm{H}_{0}$ ditolak dan $\mathrm{H}_{1}$ diterima. Seleksi berpengaruh positif dan signifikan terhadap kinerja karyawan secara parsial sebesar $\mathrm{t}_{\text {hitung }}>\mathrm{t}_{\text {tabel }}(6,889>1,996)$ pada taraf signifikansi $0,000<0,05$, artinya $\mathrm{H}_{0}$ ditolak dan $\mathrm{H}_{2}$ diterima. Sedangkan rekrutmen dan seleksi terhadap kinerja karyawan secara simultan berpengaruh positif dan signifikan sebesar $F_{\text {hitung }}>F_{\text {tabel }}(28,330>2,740)$ dengan taraf signifikansi $0,000<0,05$, artinya $\mathrm{H}_{0}$ ditolak dan $\mathrm{H}_{3}$ diterima.

Secara teoritis hasil penelitian ini akan menambah khasanah ilmu pengetahuan khususnya dalam bidang pengembangan kompetensi sumber daya manusia (SDM) yakni karyawan.
\end{abstract}

\section{Kata Kunci : Rekrutmen, Seleksi Dan Kinerja Karyawan.}




\section{PENDAHULUAN}

\section{Latar Belakang Masalah}

Kualitas sumber daya manusia merupakan merupakan komponen penting dalam setiap gerak pembangunan. Hanya dari sumber daya manusia yang berkualitas tinggilah yang dapat mempercepat pembangunan bangsa. Jumlah penduduk yang besar, apabila tidak diikuti dengan kualitas yang memadai, hanyalah akan menjadi beban pembangunan. Kualitas penduduk adalah keadaan penduduk baik secara perorangan maupun kelompok berdasarkan tingkat kemajuan yang telah dicapai.

Sumber daya manusia (SDM) merupakan hal yang vital dalam perkembangan ekonomi suatu negara, dan Indonesia dianugerahi dengan jumlahnya yang sangat melimpah. Namun, akan sangat disayangkan jika potensi sumber daya manusia (SDM)nya tidak dipersiapkan dan dikelola dengan baik karena kita tidak bisa hanya bergantung pada kekayaan alam semata yang semakin menipis. Meningkatkan kualitas sumber daya manusia (SDM) adalah harga mati bagi Indonesia bila ingin membangun ekonomi yang lebih baik nantinya agar tidak terusmenerus tertinggal dan dieksploitasi oleh negara lain.

PT. Boga Lestari Sentosa

(Kenny Rogers Roasters) Indonesia adalah perusahaan yang bergerak dibidang food and beverages (restaurant), yang dimana pemimpin harus memberikan contoh.

Pengelolaan sumber

daya manusia (SDM)

merupakan hal yang penting dalam pencapaiaan tujuan. Umumnya pimpinan perusahaan mengharapkan kinerja yang baik dari masing-masing karyawan dalam mengerjakan tugas-tugas yang diberikan oleh perusahaan. Perusahaan menyadari bahwa sumber daya manusia (SDM) merupakan modal dasar dalam proses pembangunan perusahaan bahkan nasional, oleh karena itu kualitas sumber daya manusia (SDM) senantiasa harus dikembangkan dan diarahkan agar tercapainya tujuan yang telah ditetapkan oleh perusahaan.

Adapun aktivitasaktivitas manajemen sumber daya manusia ini terdiri dari : perencanaan sumber daya manusia, pengadaan, pengarahan, pengembangan, pemeliharaan, dan pemberhentian. Hal ini ditujukan agar perusahaan dapat mengelola sumber daya manusia yang baik secara efektif dan efisien. Salah satu aktivitas dalam pengelolaan sumber daya manusia (SDM) adalah rekrutmen dan seleksi.

Sistem perekrutan dan seleksi di dalam PT. Boga Lestari Sentosa (Kenny Rogers Roasters) Indonesia tidak hanya menghasilkan karyawan yang statusnya sebagai karyawa tetap, namun untuk meningkatkan efektifitasan perusahaan maka PT. Boga Lestari Sentosa 
(Kenny Rogers Roasters) Indonesia juga menggunakan tenaga kerja yang berasal dari outsourching.

$$
\text { Dengan adanya }
$$

rekrutmen dan seleksi yang baik maka akan mampu mendukung kinerja karyawan, dimana kinerja merupakan salah satu faktor terpenting guna mencapai keberhasilan perusahaan, kinerja adalah perbandingan antara keluaran (output) dengan masukan (input).

Berdasarkan uraian di atas maka peneliti tertarik mengambil judul: "Pengaruh
Rekrutmen Dan Seleksi

Terhadap Kinerja Karyawan

Pada PT. Boga Lestari

Sentosa".

\section{Rumusan Masalah} adalah:

Adapun rumusan masalahnya

1. Seberapa besar pengaruh rekrutmen terhadap kinerja?

2. Seberapa besar pengaruh seleksi terhadap kinerja?

3. Seberapa besar pengaruh rekrutmen dan seleksi terhadap kinerja secara simultan?

\section{Kerangka Pemikiran}

\section{Pengaruh Rekrutmen dan Seleksi Terhadap Kinerja Karyawan} Pada PT Boga Lestari Sentosa

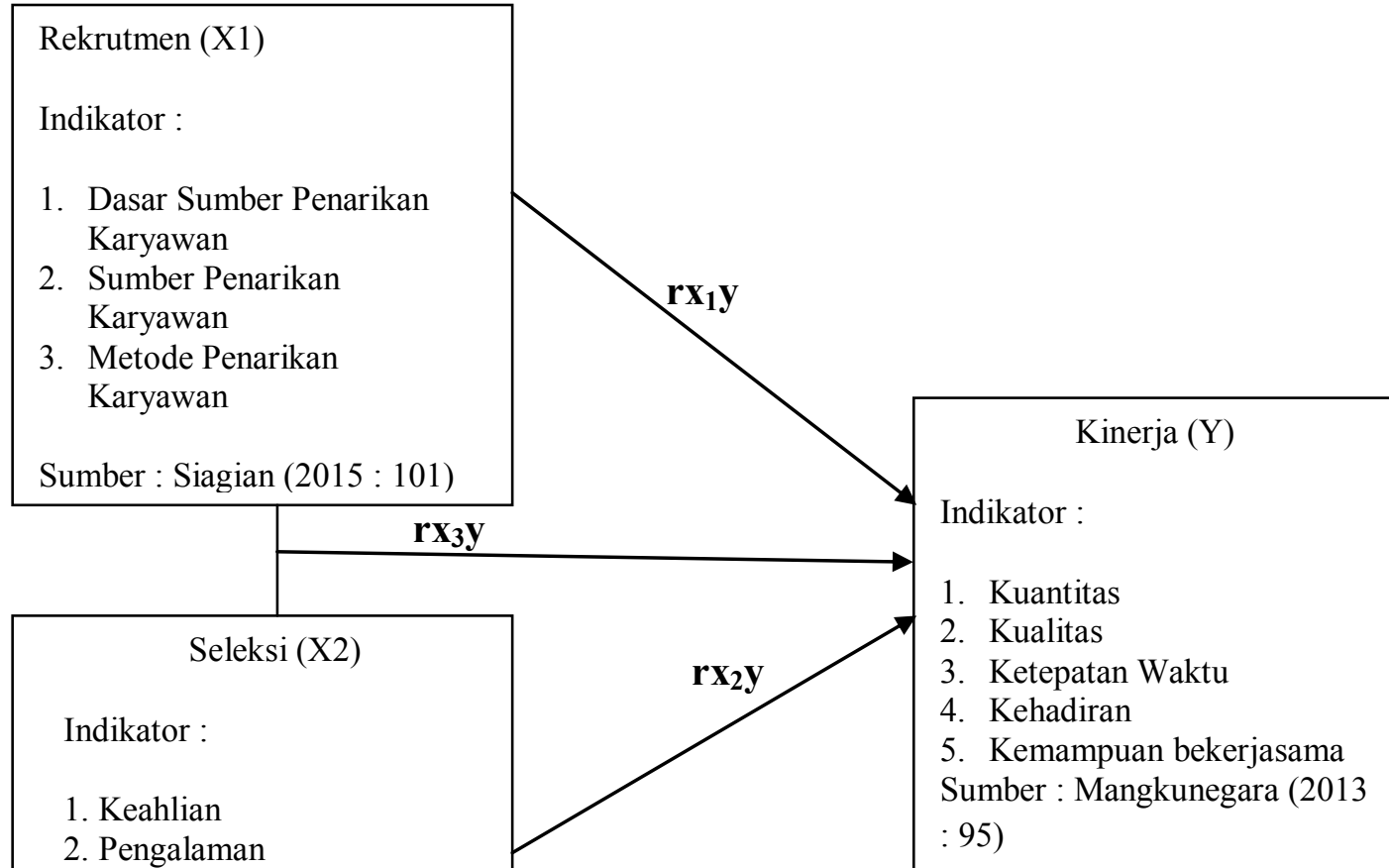

3. Umur

4. Pendidikan

Gambar 1.1. Kerangka Berfikir

5. Bakat

Sumber : Hasibuan (2011: 54) 
Keterangan :

$\mathrm{rx}_{1} \mathrm{y}:$ pengaruh rekrutmen terhadap

kinerja secara parsial

$\mathrm{rx}_{2} \mathrm{y}$ : pengaruh seleksi terhadap

kinerja secara parsial

$\mathrm{rx}_{3} \mathrm{y}$ : pengaruh rekrutmen dan

seleksi terhadap kinerja secara simultan

\section{Hipotesis Penelitian}

Berdasarkan kerangka

pemikiran yang telah dikemukakan dan dilandasi kajian teori sebelumnya, maka hipotesis pada peneliitian ini dapat dirumuskan sebagai berikut:

$\mathrm{H}_{1}=$ Diduga terdapat pengaruh positif dan signifikan rekrutmen terhadap kinerja

$\mathrm{H}_{2}=$ Diduga terdapat pengaruh positif dan signifikan seleksi terhadap kinerja

$\mathrm{H}_{3}=$ Diduga terdapat pengaruh positif dan signifikan antara rekrutmen dan seleksi terhadap kinerja secara simultan.

\section{LANDASAN TEORI \\ Rekrutmen}

Rekrutmen merupakan suatu keputusan perencanaan manajemen sumber daya manusia mengenai jumlah karyawan yang dibutuhkan, kapan diperlukan, serta kriteria apa saja yang diperlukan dalam suatu organisasi. Rekrutmen pada dasarnya merupakan usaha untuk mengisi jabatan atau pekerjaan yang kosong di lingkungan suatu organisasi atau perusahaan, untuk itu terdapat dua sumber sumber tenaga kerja yakni sumber dari luar (eksternal) organisasi atau dari dalam (internal) organisasi.

$$
\text { Penarikan (rekrutmen) }
$$

pegawai merupakan suatu proses atau tindakan yang dilakukan oleh organisasi untuk mendapatkan tambahan pegawai melalui beberapa tahapan yang mencakup identifikasi dan evaluasi sumber-sumber penarikan tenaga kerja, menentukan kebutuhan tenaga kerja, proses seleksi, penempatan, dan orientasi tenaga kerja. Penarikan pegawai bertujuan menyediakan pegawai yang cukup agar manajer dapat memilih karyawan yang memenuhi kualifikasi yang mereka perlukan (Malthis, 2001: 201).

\section{Seleksi}

Seleksi merupakan bagian materi dari operasional manajemen sumber daya manusia yaitu pengadaan (procurement), sedangkan pengadaan itu sendiri terdiri dari : perencanaan, perekrutan, seleksi, penempatan, dan produksi. Proses seleksi merupakan tahap-tahap khusus yang digunakan untuk memutuskan pelamar mana yang akan diterima. Proses tersebut dimulai ketika pelamar kerja dan diakhiri dengan keputusan penerimaan. Proses seleksi merupakan pengambilan keputusan bagi calon pelamar untuk diterima atau tidak.

Menurut Simamora (2005 : 25), seleksi merupakan proses pemilihan dari sekelompok pelamar yang paling memenuhi kriteria seleksi untuk posisi yang tersedia di dalam perusahaan. Sedangkan menurut Teguh (2009 : 17) menjelaskan bahwa seleksi adalah proses yang terdiri dari berbagai langkah yang spesifik dari kelompok pelamar yang paling cocok dan memenuhi syarat untuk jabatan tertentu 


\section{Kinerja}

Sangatlah sulit untuk menetapkan suatu definisi kinerja yang dapat memberikan pengertian yang komprehensif. Penggunaan kata kinerja sendiripun kadang-kadang disamaartikan dengan prestasi kerja, efektivitas kerja, hasil kerja, pencapaian tujuan, produktifitas kerja, dan berbagai istilah lainnya. Sesunggguhnya sekalipun ada persamaan pengertian kinerja dengan berbagai istilah tersebut, akan tetapi terdapat perbedaan pengertian dasarnya maupun prosesnya.

Menurut Mangkunegara (2013 : 67) pengertian kinerja adalah hasil kerja secara kualitas dan kuantitas yang dicapai oleh seseorang karyawan dalam melaksanakan tugasnya sesuai dengan tanggung jawab yang diberikan kepadanya.

(Stephen P. Robbins, 2001:6) menyebutkan bahwa secara sederhana Kinerja Karyawan adalah fungsi dari interaksi antara kemampuan (ability) dan Motivasi (motivation), tetapi masih ada bagian yang masih hilang dari fungsi tersebut selain kecerdasan dan keahlian dari seorang individu yang keduanya merupakan bagian dari kemampuan dan Motivasi dari setiap karyawan, yaitu kesempatan.

\section{METODE PENELITIAN}

Metode penelitian ini bersifat deskriptif kuantitatif, yaitu menggambarkan atau mendeskripsikan pengaruh hubungan sebab dan akibat dari penelitian ini. Pengumpulan data yang digunakan dalam penelitian ini antara lain observasi, penyebaran kuesioner dan wawancara. Metode yang telahdigunakandalampenelitianiniada

lahdeskriptif (kualitatif) dan verifikatif (kuantitatif) serta pengolahan data denganmenggunakanStatistical Package for Social Science (SPSS). Sampeldaripenelitianiniadalah $\quad 69$ karyawan.

\section{HASIL PENELITIAN DAN PEMBAHASAN}

\section{A. Pengujian Instrumen Dan Data Penelitian.}

Pengujian instrumen diperlukan karena memiliki kedudukan yang sangat penting guna memastikan bahwa variabel yang diteliti memiliki fungsi sebagai alat pembuktian. Adapun pengujian instrumen dan data penelitian dibahas melalui uji validitas dan reliabilitas, sebagai berikut:

\section{Pengujian Validitas Instrumen Penelitian}

Pengujian vailiditas pernyataan dilakukan untuk memastikan bahwa semua butir pernyataan yang ditetapkan benar-benar memberikan data yang akurat, sehingga bisa dipergunakan untuk memperoleh gambaran dari obyek yang diteliti secara riil sehingga butir pernyataan yang digunakan dapat diketahui valid atau tidak, dalam arti dapat dipergunakan atau tidak.

Untuk mengolah uji validitas, tiap butir pernyataan, dilakukan dengan membandingkan Chronbatch Alpha dengan standar Chronbatch Alpha 0,30 . Taraf signifikansi $\alpha=0,05$ (5\%) dengan tingkat kepercayaan pengujiannya adalah 95\%. Kriteria keputusan validitas dengan ketentuan

a. Jika chronbatch Alpha $>0,30$, maka instrumen valid, 
b. Jika chronbatch Alpha $<0,30$, maka instrumen tidak valid.

a. Uji Validitas Untuk Variabel Rekruitmen $\left(\mathrm{X}_{1}\right)$
Berikut ini hasil uji validitas untuk variabel rekruitmen $\left(\mathrm{X}_{1}\right)$ yang diolah dengan program SPSS versi 22.

Tabel 4.1

Hasil Uji Validitas Instrumen Variabel Rekruitmen $\left(\mathbf{X}_{1}\right)$

\begin{tabular}{|c|c|c|c|}
\hline Pernyataan & Chronbatch Alpha & $\begin{array}{c}\text { Standar } \\
\text { Chronbatch } \\
\text { Alpha }\end{array}$ & Keputusan \\
\hline Pernyataan 1 & 0.390 & 0.30 & Valid \\
\hline Pernyataan 2 & 0.438 & 0.30 & Valid \\
\hline Pernyataan 3 & 0.376 & 0.30 & Valid \\
\hline Pernyataan 4 & 0.571 & 0.30 & Valid \\
\hline Pernyataan 5 & 0.836 & 0.30 & Valid \\
\hline Pernyataan 6 & 0.457 & 0.30 & Valid \\
\hline Pernyataan 7 & 0.790 & 0.30 & Valid \\
\hline Pernyataan 8 & 0.838 & 0.30 & Valid \\
\hline Pernyataan 9 & 0.817 & 0.30 & Valid \\
\hline Pernyataan 10 & 0.555 & 0.30 & Valid \\
\hline
\end{tabular}

Sumber : Data primer diolah.

Dari data tabel di atas, variabel rekruitmen $\left(\mathrm{X}_{1}\right)$ diperoleh nilai Chronbatch Alpha lebih besar dari 0,30 , maka semua item pernyataan dinyatakan valid. Untuk itu kuesioner yang digunakan layak untuk diolah sebagai data penelitian.

\section{b. Uji Validitas Untuk Variabel Seleksi $\left(\mathbf{X}_{2}\right)$}

Berikut ini hasil uji validitas untuk variabel seleksi $\left(\mathrm{X}_{2}\right)$ yang diolah dengan program SPSS versi 22, terlihat pada tabel bawah ini:

Tabel 4.2

Pengujian Validitas Instrumen Pernyataan Seleksi $\left(\mathbf{X}_{2}\right)$

\begin{tabular}{|c|c|c|c|}
\hline Pernyataan & Chronbatch Alpha & $\begin{array}{c}\text { Standar } \\
\text { Chronbatch } \\
\text { Alpha }\end{array}$ & Keputusan \\
\hline Pernyataan 1 & 0.406 & 0.30 & Valid \\
\hline Pernyataan 2 & 0.528 & 0.30 & Valid \\
\hline Pernyataan 3 & 0.393 & 0.30 & Valid \\
\hline Pernyataan 4 & 0.552 & 0.30 & Valid \\
\hline Pernyataan 5 & 0.540 & 0.30 & Valid \\
\hline Pernyataan 6 & 0.386 & 0.30 & Valid \\
\hline Pernyataan 7 & 0.635 & 0.30 & Valid \\
\hline Pernyataan 8 & 0.479 & 0.30 & Valid \\
\hline Pernyataan 9 & 0.548 & 0.30 & Valid \\
\hline Pernyataan 10 & 0.502 & 0.30 & Valid \\
\hline
\end{tabular}

Sumber : Data primer diolah. 
Dari data tabel di atas, variabel seleksi $\left(\mathrm{X}_{2}\right)$ diperoleh nilai Chronbatch Alpha lebih besar dari 0,30 , maka semua item dinyatakan valid. Untuk itu kuesioner yang digunakan layak untuk diolah sebagai data penelitian.
c.Uji Validitas Untuk Variabel Kinerja Karyawan (Y)

Berikut ini hasil uji validitas untuk variabel kinerja karyawan (Y) yang diolah dengan program SPSS versi 22 , terlihat pada tabel bawah ini:

Tabel 4.3

Hasil Uji Validitas Instrumen Pernyataan Kinerja Karyawan (Y)

\begin{tabular}{|c|c|c|c|}
\hline Pernyataan & Chronbatch Alpha & $\begin{array}{c}\text { Standar } \\
\text { Chronbatch } \\
\text { Alpha }\end{array}$ & Keputusan \\
\hline Pernyataan 1 & 0.384 & 0.30 & Valid \\
\hline Pernyataan 2 & 0.517 & 0.30 & Valid \\
\hline Pernyataan 3 & 0.378 & 0.30 & Valid \\
\hline Pernyataan 4 & 0.512 & 0.30 & Valid \\
\hline Pernyataan 5 & 0.561 & 0.30 & Valid \\
\hline Pernyataan 6 & 0.509 & 0.30 & Valid \\
\hline Pernyataan 7 & 0.721 & 0.30 & Valid \\
\hline Pernyataan 8 & 0.579 & 0.30 & Valid \\
\hline Pernyataan 9 & 0.733 & 0.30 & Valid \\
\hline Pernyataan 10 & 0.687 & 0.30 & Valid \\
\hline \multicolumn{2}{|c|}{ Sumber : Data primer diolah. }
\end{tabular}

Dari data tabel di atas, variabel Kinerja karyawan (Y) diperoleh nilai Chronbatch Alpha lebih besar dari 0,30 , maka semua item dinyatakan valid. Untuk itu kuesioner yang digunakan layak untuk diolah sebagai data penelitian.

\section{Uji Reliabilitas Instrumen Penelitian}

Uji reliabilitas dimaksudkan untuk memastikan bahwa butir petanyaan yang dipergunakan dapat memberikan hasil yang kurang lebih sama apabila dilakukan pengambilan data pada waktu yang berbeda dengan obyek yang memiliki kondisi sama. Menurut Sugiyono (2016:188) "Suatu kuesioner dikatakan reliabel atau handal jika jawaban responden terhadap pernyataan adalah konsisten atau stabil dari waktu ke waktu". Untuk menguji validitas, tiap butir

pernyataan, dilakukan dengan membandingkan antara nilai Chronbatch Alpha dengan Standar Chronbatch Alpha (0.60) dengan taraf signifikansi $\alpha=0,05(5 \%)$ dan tingkat kepercayaan pengujiannya adalah 95\%. Adapun kriteria uji reliabilitas adalah sebagai berikut:

a. Jika chronbatch Alpha $>0,600$, maka instrumen reliabel,

b. Jika chronbatch Alpha $<0,60$, maka instrumen tidak reliabel.

Pengujian reliabilitas dalam penelitian ini dilakukan dengan menggunakan program SPSS Versi 22 yang hasilnya sebagai berikut :

\section{Tabel 4.4}

Hasil Uji Reliabilitas Instrumen

\begin{tabular}{|l|l|l|l|}
\hline ariabel & $\begin{array}{c}\text { batch } \\
\text { Alph } \\
\boldsymbol{a}\end{array}$ & $\begin{array}{c}\text { indar } \\
\text { Chron } \\
\text { batch } \\
\text { Alpa }\end{array}$ & usan \\
\hline Rekruitmen & 0.807 & .60 & bel \\
\hline
\end{tabular}




\begin{tabular}{|l|l|l|l|}
\hline$(\mathrm{X} 1)$ & & & \\
\hline $\begin{array}{l}\text { Seleksi } \\
(\mathrm{X} 2)\end{array}$ & 0.661 & .60 & bel \\
\hline $\begin{array}{l}\text { Kinerja } \\
\text { Karyawan } \\
(\mathrm{Y})\end{array}$ & 0.754 & .60 & bel \\
\hline
\end{tabular}

Sumber : Data primer diolah.

Berdasarkan tabel di atas, menunjukkan bahwa semua item pernyataan variabel rekruitmen $\left(\mathrm{X}_{1}\right)$, seleksi $\left(\mathrm{X}_{2}\right)$ dan kinerja karyawan (Y), dinyatakan reliabel, hal itu dibuktikan dengan diperoleh nilai Chronbatch Alpha lebih besar dari 0,60 .

\section{Pengujian Asumsi Klasik (Uji Prasyarat)}

Pengujian Asumsi Klasik digunakan untuk mengetahui ketepatan data, atau untuk mengetahui keberartian hubungan antara variabel independen dengan variabel dependen sehingga hasil analisis dapat diinterpretasikan dengan lebih akurat, efisien, dan terbatas dari kelemahan-kelemahan yang terjadi karena masih adanya gejala-gejala asumsi klasik.

Dalam penelitian ini, teknik analisis data dilakukan dengan menggunakan program SPSS versi 22. Dalam penelitian ini uji asumsi klasik yang dilakukan adalah terdiri dari pengujian normalitas, uji multikolinearitas, uji autokorelasi, dan uji heteroskedastisitas.

\section{a. Uji Normalitas}

Uji normalitas dimaksudkan untuk menguji apakah dalam model regresi variabel dependen dan variabel independen memiliki distribusi normal atau tidak. Dalam pengujian ini dilakukan dengan mengamati histogram atas nilai residual dan grafik normal probability plot. Deteksi pengambilan keputusan adalah dengan syarat titik-titik menyebar disekitar garis dan mengikuti arah garis diagonal. Adapun hasil uji normalitas adalah sebagai berikut

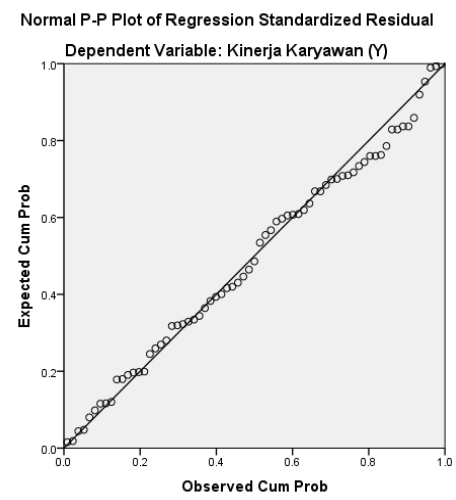

Sumber : Data diolah

Gambar 4.2

P-P Plot Uji Normalitas - Diagram Penyebaran Titik Residual

Pada gambar grafik di atas dapat dilihat bahwa grafik normal probability plot menunjukkan pola grafik yang normal. Hal ini terlihat dari titik-titik yang menyebar disekitar grafik normal/mengikuti garis diagonal.

\section{b. Uji Multikolinearitas}

Pengujian mutlikolinearitas dilakukan untuk meyakini bahwa antar variabel bebas tidak memiliki multikolinearitas atau tidak memiliki hubungan korelasi antara variabel yang ditetapkan sebagai model dalam penelitian, karena model regresi yang baik seharusnya tidak terjadi korelasi di antara variabel independen. Uji multikolinearitas dapat dilakukan dengan melihat nilai Tolerance Value dan Variance Inflation Factor (VIF).

Adapun sebagai prasyarat adalah sebagai berikut : 
1) Jika nilai VIF $>10$ dan nilai tolerance value $>1$ maka terjadi gejala multikolinearitas

2) Jika nilai VIF $<10$ dan nilai tolerance value $<1$ maka tidak terjadi gejala multikolinearitas.

Pengujian multikolinearitas dilakukan dengan menggunakan SPSS. Versi 22 dengan hasil sebagai berikut :

Tabel 4.6

\section{Hasil PengujianMultikolinearitas Dengan Collinearity}

StatisticKinerja Karyawan

Sebagai Variabel Dependen Coefficients

\begin{tabular}{|c|c|c|c|c|c|c|c|}
\hline \multirow[t]{2}{*}{ Model } & \multicolumn{2}{|c|}{$\begin{array}{l}\text { Unsta } \\
\text { ndardi } \\
\text { zed } \\
\text { Coeffi } \\
\text { cients }\end{array}$} & $\begin{array}{l}\text { Sta } \\
\text { nda } \\
\text { rdiz } \\
\text { ed } \\
\text { Coe }\end{array}$ & \multirow[t]{2}{*}{$t$} & \multirow[t]{2}{*}{$\begin{array}{l}S \\
\text { i } \\
g\end{array}$} & \multicolumn{2}{|c|}{$\begin{array}{c}\text { Collin } \\
\text { earity } \\
\text { Statis } \\
\text { tics }\end{array}$} \\
\hline & B & $\begin{array}{l}S \\
t \\
d\end{array}$ & $\begin{array}{c}\text { Bet } \\
\text { a }\end{array}$ & & & $\begin{array}{l}\mathrm{T} \\
\mathrm{O} \\
\mathrm{I}\end{array}$ & $\begin{array}{l}\mathrm{V} \\
\mathrm{I} \\
\mathrm{F}\end{array}$ \\
\hline $\begin{array}{ll}1 & \text { (Co } \\
& \text { nst } \\
& \text { ant } \\
& \text { ) }\end{array}$ & $\begin{array}{l}9 \\
2 \\
2 \\
7 \\
1\end{array}$ & $\begin{array}{l}4 \\
0 \\
0 \\
0 \\
8\end{array}$ & & $\begin{array}{l}2 \\
3 \\
1 \\
3 \\
\end{array}$ & $\begin{array}{l}0 \\
2 \\
4\end{array}$ & & \\
\hline $\begin{array}{l}\text { Re } \\
\text { krui } \\
\text { tm } \\
\text { en } \\
(X 1 \\
\text { ) }\end{array}$ & $\begin{array}{l}2 \\
2 \\
7\end{array}$ & $\begin{array}{l}0 \\
9 \\
4\end{array}$ & $\begin{array}{r}.25 \\
8\end{array}$ & $\begin{array}{l}4 \\
0 \\
9\end{array}$ & $\begin{array}{l}0 \\
1 \\
9\end{array}$ & $\begin{array}{l}7 \\
1 \\
3\end{array}$ & $\begin{array}{l}4 \\
0 \\
3\end{array}$ \\
\hline $\begin{array}{l}\text { Sel } \\
\text { eks } \\
\text { i } \\
(X 2 \\
)^{\prime}\end{array}$ & $\begin{array}{l}5 \\
6 \\
0\end{array}$ & $\begin{array}{l}1 \\
1 \\
8\end{array}$ & $\begin{array}{r}.50 \\
6\end{array}$ & $\begin{array}{l}7 \\
3 \\
0\end{array}$ & $\begin{array}{l}0 \\
0 \\
0\end{array}$ & $\begin{array}{l}7 \\
1 \\
3\end{array}$ & $\begin{array}{l}4 \\
0 \\
3\end{array}$ \\
\hline
\end{tabular}

a. Dependent Variable: Kinerja Karyawan (Y)

Sumber : Data primer diolah.

Berdasarkan tabel pengujian multikolinieritas pada tabel di atas diperoleh nilai tolerance masingmasing variabel bebas yaitu rekruitmen 0,713 dan seleksi sebesar 0,713 dimana nilai tersebut kurang dari 1, sedangkan nilai Variance Inflation Factor (VIF) variabel rekruitmen sebesar 1,403 dan seleksi sebesar 1,403 dimana nilai tersebut kurang dari 10, dengan demikian model regresi ini tidak ada multikolinearitas.

\section{c. Uji Autokorelasi}

Pengujian Autokorelasi digunakan untuk mengetahui ada atau tidaknya penyimpangan korelasi antar anggota sampel. Untuk mengetahui adanya autokorelasi dilakukan pengujian Durbin-Watson (DW) dengan membandingkan nilai DurbinWatson dengan kriteria atau pedoman dalam interpretasi. Adapun kriteria pedoman Uji Darbin-Watson (DWtest)yang menjadi acuannya adalah sebagai berikut ini :

Tabel 4.7

Pedoman Interpretasi Uji DurbinWatson

\begin{tabular}{|c|c|}
\hline Kriteria & Keterangan \\
\hline$<1,0$ & Ada autokorelasi \\
\hline $1,10-1,56$ & $\begin{array}{c}\text { Tanpa } \\
\text { kesimpulan } \\
\text { Tidak ada } \\
\text { autokorelasi }\end{array}$ \\
\hline $\mathbf{1 , 5 5}-\mathbf{2 4 6}$ & $\begin{array}{c}\text { Tanpa } \\
\text { kesimpulan }\end{array}$ \\
\hline $2,46-2,90$ & Ada autokorelasi \\
\hline$>2,90$ & \\
\hline
\end{tabular}

Adapun hasil pengujian autokorelasi adalah sebagai berikut:

Tabel 4.8

Uji Durbin-Watson Model Summary ${ }^{\mathrm{D}}$

\begin{tabular}{|c|c|c|c|c|c|}
\hline $\begin{array}{l}\text { Mo } \\
\text { del }\end{array}$ & $\mathrm{R}$ & $\begin{array}{c}\mathrm{R} \\
\text { Squ } \\
\text { are }\end{array}$ & $\begin{array}{c}\text { Adju } \\
\text { sted } \\
\text { R } \\
\text { Squa } \\
\text { re }\end{array}$ & $\begin{array}{l}\text { Std. } \\
\text { Error } \\
\text { of } \\
\text { the } \\
\text { Esti } \\
\text { mate }\end{array}$ & $\begin{array}{l}\text { Dur } \\
\text { bin- } \\
\text { Wat } \\
\text { son }\end{array}$ \\
\hline
\end{tabular}




\begin{tabular}{|l|r|r|r|r|r|}
\hline 1 & .68 & .462 & .446 & 2.94 & 1.85 \\
& $0^{\mathrm{a}}$ & .462 & 9 \\
\hline
\end{tabular}

Sumber : Data primer diolah.

Berdasarkan hasil pengujian pada tabel di atas, model regresi ini tidak ada autokorelasi, hal ini dibuktikan dengan nilai Durbin-Watson sebesar 1.857 yang berada diantara interval $1.550-2.460$.

\section{d. Uji Heteroskedastisitas}

Ujiheteroskedastisitas dimaksudkan untuk menguji apakah dalam model regresi terjadi ketidaksamaan varians residual dari satu pengamatan ke pengamatan lain. Salah satu cara untuk mendeteksi terjadi heteroskedastisitas atau tidak adalah dengan melihat grafik scatter plot pada nilai prediksi variabel terikat (ZPRED) dan nilai residualnya (SRESID). Kriteria pengambilan keputusan adalah jika titik-titik pada gambar yang dihasilkan membentuk pola tertentu yang teratur maka telah terjadi heteroskedastisitas. Namun jika menyebar tanpa membentuk pola tertentu, maka model tersebut tidak terjadi heteroskedastisitas. Adapun hasil uji heteroskedastisitas dapat dilihat pada gambar berikut ini:

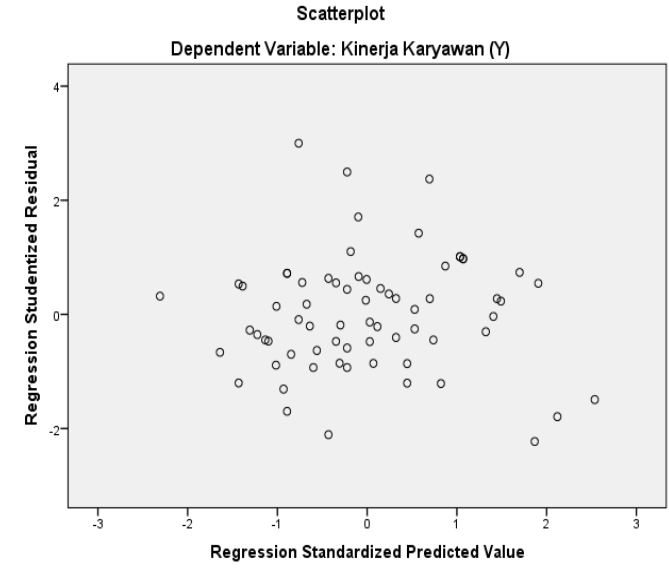

Sumber : Data diolah

Gambar 4.3
Pada gambar di atas, titik-titik pada grafik scatterplot tidak mempunyai pola penyebaran yang jelas dan titik-titik tersebut menyebar di atas dan dibawah angka 0 pada sumbu Y, dengan demikian hal ini menunjukkan bahwa tidak terdapat gangguan heteroskedastisitas.

\section{Analisis Data Deskriptif dan Verifikatif}

\section{Analisis Deskriptif Responden}

Sebelum disampaikan analisis deskriptif penilaian keadaan responden menurut indikator dan variabel. Berikut ini deskripsi karakteristik responden meliputi jenis kelamin, usia dan pendidikan, sebagai berikut :

a.Responden BerdasarkanJenis

Kelamin

Tabel 4.10

Karakteristik Responden

Berdasarkan Jenis Kelamin Jenis kelamin

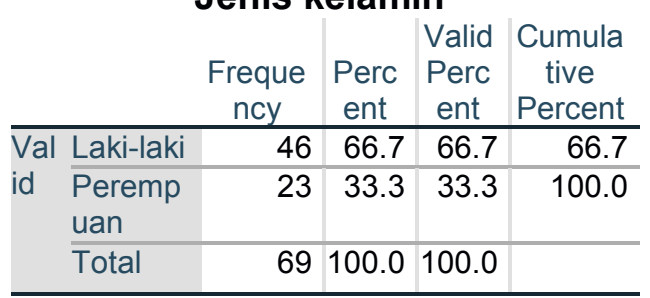

Sumber : Data Primer diolah

Dari data tabel di atas, dapat dilihat bahwa dari 69 responden menunjukkan bahwa responden yang berjenis kelamin laki-laki sebanyak 46 orang atau $66,7 \%$, sedangkan responden yang berjenis kelamin perempuan sebanyak 23 orang atau $33, \%$. Dapat disimpulkan bahwa responden yang berjenis kelamin laki-laki lebih dominan sebanyak 46 orang atau $66,7 \%$.

b. Responden Berdasarkan Usia

Hasil Uji Heteroskedastisitas 
Tabel 4.11

Karakteristik Responden

Berdasarkan Usia Usia

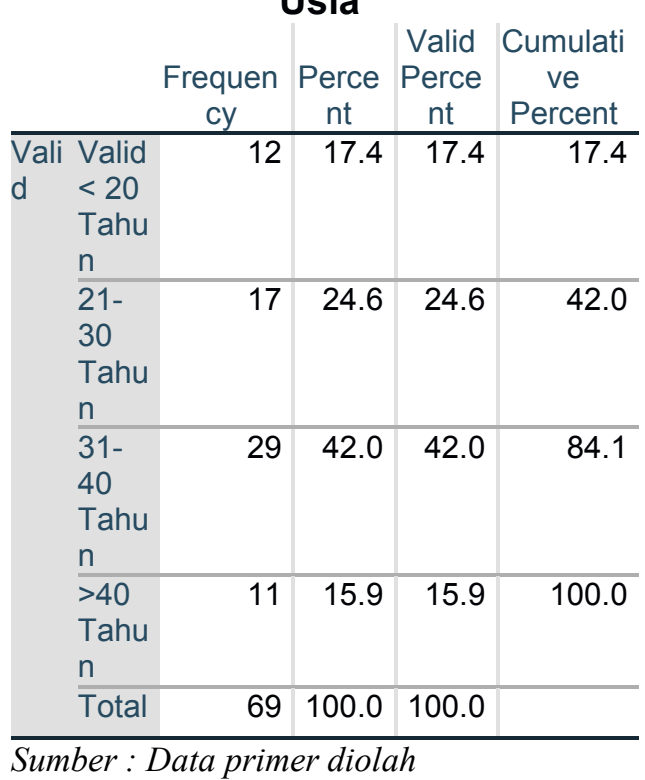

Berdasarkan data tabel di atas, responden yang berusia antara $<20$ tahun sebanyak 12 orang atau $17,4 \%$, usia antara 21-30 tahun sebanyak 17 orang atau $24,6 \%$, yang berusia antara 31-40 tahun sebanyak 29 orang atau $42 \%$ dan yang berusia diatas 40 tahun sebanyak 11 orang atau 15,9\%. Dapat disimpulkan bahwa responden yang dominasi usia terdapat pada usia 31-40 tahun sebanyak 29 orang atau $42 \%$.

c. Responden Berdasarkan Pendidikan

Tabel 4.12

Karakteristik Responden Berdasarkan Pendidikan Pendidikan

\begin{tabular}{|c|c|c|c|c|c|}
\hline & & $\begin{array}{c}\text { Frequen } \\
\text { cy }\end{array}$ & $\begin{array}{c}\text { Perce } \\
\text { nt }\end{array}$ & $\begin{array}{c}\text { Valid } \\
\text { Perce } \\
\text { nt }\end{array}$ & $\begin{array}{c}\text { Cumulati } \\
\text { ve } \\
\text { Percent }\end{array}$ \\
\hline $\begin{array}{l}\text { Vali } \\
\text { d }\end{array}$ & $\begin{array}{l}\text { Valid } \\
\text { SLTA }\end{array}$ & 14 & 20.3 & 20.3 & 20.3 \\
\hline & $\begin{array}{l}\text { Diplo } \\
\text { ma }\end{array}$ & 6 & 8.7 & 8.7 & 29.0 \\
\hline & S1 & 34 & 49.3 & 49.3 & 78.3 \\
\hline & $\overline{\mathrm{S} 2}$ & 15 & 21.7 & 21.7 & 100.0 \\
\hline & Total & 69 & 100.0 & 100.0 & \\
\hline
\end{tabular}

Sumber : Data primer diolah

Berdasarkan data tabel di atas, menunjukkan bahwa dari sejumlah 69 responden yang berpendidikan SLTA sebanyak 14 orang atau 20,3\%, berpendidikan Diploma sebanyak 6 orang atau $8,7 \%, \mathrm{~S} 1$ sebanyak 34 orang atau 49,3\%, dan yang berpendidikan S2 sebanyak 15 orang atau $21,7 \%$. Dapat disimpulkan bahwa responden berdasarkan pendidikan di dominasi S1 sebanyak 34 orang atau 49,3\%.

\section{Analisis Deskriptif Penilaian Variabel}

Analisis deskriptif dimaksudkan untuk menganalisis data dengan cara mendeskripsikan data yang telah terkumpul dengan berdasar pada variabel yang telah ditetapkan sebagai model dalam penelitian. Menurut Sugiyono (2016:95) berpendapat "Skala pengukuran merupakan kesepakatan yang digunakan sebagai acuan untuk menentukan panjang pendeknya interval yang ada dalam alat ukur sehingga bila digunakan dalam pengukuran akan menghasilkan data”. Untuk memberikan interpretasi nilai rata-rata dari tanggapan responden, dapat dikelompokkan menjadi kriteria berikut ini:

Tabel 4.14

Tabel Kriteria Tanggapan

Responden

\begin{tabular}{|c|c|}
\hline Nilai rata-rata & $\begin{array}{c}\text { Keterangan / } \\
\text { Kriteria }\end{array}$ \\
\hline $1,00-1,790$ & Sangat tidak baik \\
\hline $1,80-2,59$ & Tidak baik \\
\hline $2,60-3,39$ & Kurang baik \\
\hline $3,40-4,19$ & Baik \\
\hline $4,19-5,00$ & Sangat baik \\
\hline
\end{tabular}


Selanjutnya dicari rata-rata dari setiap jawaban responden. Untuk memudahkan penilaian ratarata tersebut maka digunakan interval, untuk menentukan panjang kelas interval, F.S Sobana (2008:1) digunakan rumus sebagai berikut :

Panjang kelas interval =

\section{Rentang Nilai}

\section{Banyak Kelas Interval}

Rentang nilai $=$ nilai tertinggi - nilai terendah atau $5-1=4$
Banyak kelas interval $=5$, maka panjang kelas interval $=4 / 5=0,8$

Berdasarkan kriteria di atas, berikut ini penilain keadaan responden menurut indikator dan variabel sebagai berikut :

a. Jawaban Responden Berdasar Pada Variabel Rekruitmen $\left(\mathbf{X}_{1}\right)$

Kriteria dari obyek yang diteliti berdasarkan pada tanggapan responden pada butir pernyataan tentang variabel rekruitmen $\left(\mathrm{X}_{1}\right)$ yang diberikan adalah sebagaiberikut:

Tabel 4.15

Jawaban Responden Berdasar Pada Butir Pernyataan Variabel Rekruitmen $\left(\mathrm{X}_{1}\right)$

\begin{tabular}{|c|c|c|c|c|c|c|c|}
\hline \multirow[t]{2}{*}{ Pernyataan } & \multicolumn{5}{|c|}{ Kriteria Jawaban } & \multirow[t]{2}{*}{ Jumlah } & \multirow[t]{2}{*}{ Skor } \\
\hline & STS & TS & KS/R & S & SS & & \\
\hline Pernyataan 1 & 0 & 2 & 23 & 29 & 15 & 69 & 3.83 \\
\hline Pernyataan 2 & 0 & 2 & 21 & 35 & 11 & 69 & 3.80 \\
\hline Pernyataan 3 & 0 & 2 & 24 & 35 & 8 & 69 & 3.71 \\
\hline Pernyataan 4 & 0 & 3 & 20 & 28 & 18 & 69 & 3.88 \\
\hline Pernyataan 5 & 0 & 0 & 20 & 31 & 18 & 69 & 3.97 \\
\hline Pernyataan 6 & 0 & 1 & 20 & 36 & 12 & 69 & 3.86 \\
\hline Pernyataan 7 & 0 & 0 & 18 & 34 & 17 & 69 & 3.99 \\
\hline Pernyataan 8 & 0 & 0 & 19 & 34 & 16 & 69 & 3.96 \\
\hline Pernyataan 9 & 0 & 0 & 23 & 31 & 15 & 69 & 3.88 \\
\hline Pernyataan 10 & 0 & 0 & 30 & 29 & 10 & 69 & 3.71 \\
\hline Jumlah & 0 & 10 & 218 & 322 & 140 & 690 & \\
\hline Persentase (\%) & $0.0 \%$ & $1.4 \%$ & $31.6 \%$ & $46.7 \%$ & $20.3 \%$ & $100 \%$ & 3.86 \\
\hline
\end{tabular}

Sumber : Data Primerdiolah

Berdasarkan pada tabel di atas, dapat diketahui bahwa keadaan atau kriteria obyek yang diteliti berdasar pada butir pernyataan semua dalam keadaan baik. Secara keseluruhan untuk kuesioner variabel rekruitmen $\left(\mathrm{X}_{1}\right)$ diperoleh rata-rata score sebesar 3.86 dengan kriteria baik. Dari ketiga indikator tersebut yang mendapatkan rattingscore yang paling rendah adalah indikator metode penarikan terutama pada pernyataan nomor 10 dimana hanya mencapai score 3,71

meskipun termasuk dalam kategori baik namun responden yang memberikan jawaban sangat tidak setuju, tidak setuju dan ragu-ragu sebesar $(0,0 \%+1,4 \%+31,6 \%)=$ $33,0 \%$.

b. Jawaban Responden Berdasar Pada Variabel Seleksi $\left(\mathbf{X}_{2}\right)$

Kriteria obyek yang diteliti berdasarkan pada tanggapan responden pada butir pernyataan seleksi $\left(\mathrm{X}_{2}\right)$ yang diberikan sebagi berikut: 
Tabel 4.16

Jawaban Responden Berdasar Pada Butir Pernyataan Variabel

Seleksi $\left(\mathbf{X}_{2}\right)$

\begin{tabular}{|l|c|c|c|c|c|c|c|}
\hline \multirow{2}{*}{ ernyataan } & \multicolumn{5}{|c|}{ Kriteria Jawaban } & Jumlah & Skor \\
\cline { 2 - 6 } & STS & TS & KS/R & S & SS & & \\
\hline Pernyataan 1 & 0 & 1 & 19 & 38 & 11 & 69 & 3.86 \\
\hline Pernyataan 2 & 0 & 0 & 27 & 27 & 15 & 69 & 3.83 \\
\hline Pernyataan 3 & 0 & 1 & 26 & 28 & 14 & 69 & 3.80 \\
\hline Pernyataan 4 & 0 & 2 & 21 & 31 & 15 & 69 & 3.86 \\
\hline Pernyataan 5 & 0 & 2 & 31 & 26 & 10 & 69 & 3.64 \\
\hline Pernyataan 6 & 0 & 0 & 17 & 39 & 13 & 69 & 3.94 \\
\hline Pernyataan 7 & 0 & 0 & 27 & 27 & 15 & 69 & 3.83 \\
\hline Pernyataan 8 & 0 & 0 & 26 & 34 & 9 & 69 & 3.75 \\
\hline Pernyataan 9 & 0 & 0 & 19 & 41 & 9 & 69 & 3.86 \\
\hline Pernyataan 10 & 0 & 0 & 29 & 33 & 7 & 69 & 3.68 \\
\hline Jumlah & $\mathbf{0}$ & $\mathbf{6}$ & $\mathbf{2 4 2}$ & $\mathbf{3 2 4}$ & $\mathbf{1 1 8}$ & $\mathbf{6 9 0}$ & \\
\hline Persentase (\%) & $\mathbf{0 . 0 \%}$ & $\mathbf{0 . 9 \%}$ & $\mathbf{3 5 . 1 \%}$ & $\mathbf{4 7 . 0 \%}$ & $\mathbf{1 7 . 1 \%}$ & $\mathbf{1 0 0 \%}$ & $\mathbf{3 . 8 0}$ \\
\hline
\end{tabular}

Sumber : Data Primerdiolah

Berdasarkan pada tabel di atas, dapat diketahui bahwa keadaan atau kriteria obyek yang diteliti berdasar pada butir pernyataan semua dalam keadaan baik. Secara keseluruhan untuk kuesioner variabel seleksi $\left(\mathrm{X}_{2}\right)$ diperoleh rata-rata score sebesar 3.80 dengan kriteria baik. Dari kelimaindikator tersebut yang mendapatkan rattingscore yang paling rendah adalah indikator umur terutama pada pernyataan nomor 5 dimana hanya mencapai score 3,64 meskipun

Tabel 4.17

termasuk dalam kategori baik namun responden yang memberikan jawaban sangat tidak setuju, tidak setuju dan ragu-ragu sebesar $(0,0 \%+$ $0,9 \%+35,1 \%)=35,9 \%$.

\section{c. Jawaban Responden Berdasar Pada Variabel Kinerja Karyawan (Y)}

Kriteria obyek yang diteliti berdasarkan pada tanggapan responden pada butir pernyataan kinerja karyawan (Y) yang diberikan sebagi

berikut:

Jawaban Responden Berdasar Pada Butir Pernyataan Variabel Kinerja

Karyawan (Y)

\begin{tabular}{|c|c|c|c|c|c|c|c|}
\hline \multirow[t]{2}{*}{ Pernyataan } & \multicolumn{5}{|c|}{ Kriteria Jawaban } & \multirow[t]{2}{*}{ Jumlah } & \multirow[t]{2}{*}{ Skor } \\
\hline & STS & TS & $\mathrm{KS} / \mathrm{R}$ & $\mathrm{S}$ & SS & & \\
\hline Pernyataan 1 & 0 & 0 & 17 & 42 & 10 & 69 & 3.90 \\
\hline Pernyataan 2 & 0 & 1 & 21 & 32 & 15 & 69 & 3.88 \\
\hline Pernyataan 3 & 0 & 1 & 29 & 30 & 9 & 69 & 3.68 \\
\hline Pernyataan 4 & 0 & 1 & 12 & 35 & 21 & 69 & 4.10 \\
\hline Pernyataan 5 & 0 & 2 & 29 & 24 & 14 & 69 & 3.72 \\
\hline Pernyataan 6 & 0 & 0 & 21 & 39 & 9 & 69 & 3.83 \\
\hline Pernyataan 7 & 0 & 0 & 15 & 31 & 23 & 69 & 4.12 \\
\hline Pernyataan 8 & 0 & 0 & 16 & 38 & 15 & 69 & 3.99 \\
\hline Pernyataan 9 & 0 & 0 & 19 & 29 & 21 & 69 & 4.03 \\
\hline
\end{tabular}




\begin{tabular}{|c|c|c|c|c|c|c|c|}
\hline Pernyataan 10 & 0 & 0 & 10 & 44 & 15 & 69 & 4.07 \\
\hline Jumlah & $\mathbf{0}$ & $\mathbf{5}$ & $\mathbf{1 8 9}$ & $\mathbf{3 4 4}$ & $\mathbf{1 5 2}$ & $\mathbf{6 9 0}$ & \\
\hline Persentase (\%) & $\mathbf{0 . 0 \%}$ & $\mathbf{0 . 7 \%}$ & $\mathbf{2 7 . 4 \%}$ & $\mathbf{4 9 . 9 \%}$ & $\mathbf{2 2 . 0 \%}$ & $\mathbf{1 0 0 \%}$ & $\mathbf{3 . 9 3}$ \\
\hline
\end{tabular}

Sumber : Data Primerdiolah

Berdasar pada tabel di atas, keadaan atau kriteria obyek yang diteliti berdasar pada butir pernyataan semua dalam keadaan baik. Secara keseluruhan untuk kuesioner variabel kinerja karyawan (Y) diperoleh ratarata score sebesar 3.93 dengan kriteria baik. Dari kelima indikator tersebut yang mendapatkan rattingscore yang paling rendah adalah indikator kuantitas terutama pada pernyataan nomor 3 dimana hanya mencapai score 3,68 meskipun termasuk dalam kategori baik namun responden yang memberikan jawaban sangat tidak setuju, tidak setuju dan ragu-ragu

sebesar $(0,0 \%+0,74 \%+24,4 \%)=$ $28,1 \%$.

\section{Analisis Verifikatif}

Analisis verifikatif dimaksudkan untuk mengetahui besaran pengaruh dan menganalisis signifikansi dari perngaruh tersebut. Pada analisis ini dilakukan terhadap pengaruh dari 2 variabel bebas terhadap variabel terikat.

\section{a. Analisis Regresi Linier \\ Berganda.}

Uji regresi berganda pada penelitian ini dimaksudkan untuk mengetahui seberapa besar pengaruh rekruitmen $\left(\mathrm{X}_{1}\right)$ dan seleksi $\left(\mathrm{X}_{2}\right)$ terhadap kinerja karyawan $(\mathrm{Y})$. Berikut ini hasil pengujian regresi dengan SPSS versi 22 yang dapat dilihat pada tabel berikut ini :
Tabel 4.18

Hasil Pengujian Regresi Berganda Coefficients $^{\mathrm{a}}$

\begin{tabular}{|c|c|c|c|c|c|}
\hline \multirow[t]{2}{*}{ Model } & \multicolumn{2}{|c|}{$\begin{array}{l}\text { Unstand } \\
\text { ardized } \\
\text { Coefficie } \\
\text { nts }\end{array}$} & \multirow{2}{*}{$\begin{array}{c}\text { Stand } \\
\text { ardize } \\
\text { d } \\
\text { Coeffi } \\
\text { cients } \\
\text { Beta }\end{array}$} & \multirow[t]{2}{*}{$t$} & \multirow[t]{2}{*}{$\begin{array}{l}\text { Si } \\
\text { g. }\end{array}$} \\
\hline & $B$ & $\begin{array}{l}\text { St } \\
\text { d. } \\
\text { Err } \\
\text { or }\end{array}$ & & & \\
\hline $\begin{array}{ll} & \text { (Con } \\
& \text { stant) }\end{array}$ & $\begin{array}{r}9 . \\
27 \\
1\end{array}$ & $\begin{array}{r}4.0 \\
08\end{array}$ & & $\begin{array}{r}2 . \\
31 \\
3\end{array}$ & $\begin{array}{l}.0 \\
2 \\
4\end{array}$ \\
\hline $\begin{array}{l}\text { Rekr } \\
\text { uitme } \\
\mathrm{n} \\
(\mathrm{X} 1)\end{array}$ & $\begin{array}{r}.2 \\
27\end{array}$ & $\begin{array}{r}.09 \\
4\end{array}$ & .258 & $\begin{array}{r}2 . \\
40 \\
9\end{array}$ & $\begin{array}{l}.0 \\
1 \\
9\end{array}$ \\
\hline $\begin{array}{l}\text { Selek } \\
\text { si } \\
(X 2)\end{array}$ & $\begin{array}{r}.5 \\
60\end{array}$ & $\begin{array}{r}11 \\
8\end{array}$ & .506 & $\begin{array}{r}4 . \\
73 \\
0\end{array}$ & $\begin{array}{l}.0 \\
0 \\
0\end{array}$ \\
\hline
\end{tabular}

a. Dependent Variable: Kinerja karyawan (Y)

Sumber : Data Primer diolah

Berdasarkan hasil perhitungan regresi pada tabel di atas, diperoleh persamaan regresi $\mathrm{Y}=9,271+$ $0,227 \mathrm{X}_{1}+0,560 \mathrm{X}_{2}$. Dari persamaan ini maka dapat disimpulkan sebagai berikut:

1) Nilai konstanta sebesar 9,271 diartikan bahwa jika variabel rekruitmen $\left(\mathrm{X}_{1}\right)$ dan seleksi $\left(\mathrm{X}_{2}\right)$ tidak ada maka telah terdapat nilai kinerja karyawan (Y) sebesar 9,271 point.

2) Nilai coefficient beta 0,227 diartikan apabila konstanta tetap dan tidak ada perubahan pada variabel seleksi $\left(\mathrm{X}_{2}\right)$, maka setiap perubahan 1 unit pada variabel rekruitmen $\left(\mathrm{X}_{1}\right)$ maka akan mengakibatkan terjadinya perubahan pada kinerja karyawan (Y) sebesar 0,227 point.

3) Nilai coefficient beta 0,560 diartikan apabila konstanta tetap 
dan tidak ada perubahan pada variabel rekruitmen $\left(\mathrm{X}_{1}\right)$, maka setiap perubahan 1 unit pada variabel seleksi $\left(\mathrm{X}_{2}\right)$, maka akan mengakibatkan terjadinya perubahan pada kinerja karyawan (Y) sebesar 0,560 point.

b. Analisis Koefisien Korelasi (r).

Analisa koefisien korelasi dimaksudkan untuk mengetahui tingkat hubungan antara variabel independen terhadap variabel dependen. Adapun hasil pengolahan data sebagai berikut:

Tabel 4.19

\section{Hasil Analisis Koefisien Korelasi Secara Parsial Antara Variabel Rekruitmen $\left(\mathrm{X}_{1}\right)$ Terhadap Kinerja Karyawan (Y) Correlations}

\begin{tabular}{|ll|r|r|}
\hline & \multicolumn{1}{|c|}{$\begin{array}{c}\text { Rekruit } \\
\text { men } \\
(\mathrm{X} 1)\end{array}$} & \multicolumn{1}{|c|}{$\begin{array}{c}\text { Kinerja } \\
\text { Karyaw } \\
\text { an (Y) }\end{array}$} \\
\hline $\begin{array}{l}\text { Rekruit } \\
\text { men } \\
(\mathrm{X} 1)\end{array}$ & $\begin{array}{l}\text { Pearson } \\
\text { Correlati } \\
\text { on } \\
\text { Sig. (2- } \\
\text { tailed) } \\
\text { N }\end{array}$ & 1 & $.529^{* *}$ \\
& $\begin{array}{l}\text { Pearson } \\
\text { Correlati } \\
\text { on } \\
\text { Kinerja }\end{array}$ & $.529^{* *}$ & .000 \\
$\begin{array}{l}\text { Karyawa (2- } \\
\text { n (Y) }\end{array}$ & .000 & 1 \\
& $\begin{array}{l}\text { tailed) } \\
\text { N }\end{array}$ & 69 & 69 \\
\hline
\end{tabular}

Berdasarkan tabel di atas, diperoleh nilai $R$ (koefisien korelasi) sebesar 0,529 artinya kedua variabel mempunyai tingkat pengaruh atau hubungan yang sedang.

Tabel 4.20

Hasil Analisis Koefisien Korelasi Secara Parsial Antara Variabel Seleksi $\left(\mathbf{X}_{2}\right)$ Terhadap Kinerja Karyawan (Y) Correlations

\begin{tabular}{|l|c|c|}
\hline & $\begin{array}{c}\text { Selek } \\
\text { si } \\
(\mathrm{X} 2)\end{array}$ & $\begin{array}{c}\text { Kinerja } \\
\text { Karyawa } \\
\mathrm{n}(\mathrm{Y})\end{array}$ \\
\hline Seleksi _ Pearson & 1 & .644 \\
\hline
\end{tabular}

\begin{tabular}{|ll|r|r|}
\hline (X2) & $\begin{array}{l}\text { Correlatio } \\
\mathrm{n} \\
\text { Sig. (2- } \\
\text { tailed) } \\
\mathrm{N}\end{array}$ & 69 & .000 \\
\hline $\begin{array}{l}\text { Kinerja } \\
\text { Karyawa } \\
\mathrm{n}(\mathrm{Y})\end{array}$ & $\begin{array}{l}\text { Pearson } \\
\text { Correlatio }\end{array}$ & $.644^{* *}$ & 69 \\
& $\mathrm{n}$ \\
& $\begin{array}{l}\text { Sig. (2- } \\
\text { tailed) }\end{array}$ & .000 & 1 \\
\hline & $\mathrm{N}$ & 69 & 69 \\
\hline
\end{tabular}

Sumber : Data Primer diolah.

Berdasarkan tabel di atas, diperoleh nilai $R$ (koefisien korelasi) sebesar 0,644 artinya kedua variabel mempunyai tingkat pengaruh atau hubungan yang kuat.

Tabel 4.21

Hasil Analisis Koefisien Korelasi Secara Simultan Antara Variabel Rekruitmen $\left(X_{1}\right)$, dan Seleksi $\left(X_{3}\right)$ Terhadap Kinerja Karyawan (Y) Model Summary

\begin{tabular}{|l|c|c|c|c|}
\hline $\begin{array}{l}\text { Mod } \\
\text { el }\end{array}$ & $\mathrm{R}$ & $\begin{array}{c}\mathrm{R} \\
\text { Squa } \\
\text { re }\end{array}$ & $\begin{array}{c}\text { Adjust } \\
\text { ed R } \\
\text { Squar } \\
\mathrm{e}\end{array}$ & $\begin{array}{c}\text { Std. } \\
\text { Error } \\
\text { of the } \\
\text { Estim } \\
\text { ate }\end{array}$ \\
\hline 1 & $\begin{array}{c}.68 \\
0^{\mathrm{a}}\end{array}$ & .462 & .446 & 2.949 \\
\hline
\end{tabular}

a. Predictors: (Constant), Seleksi (X2),

Rekruitmen (X1)

n Sumber : Data Primer diolah.

Berdasarkan tabel di atas, diperoleh nilai $R$ (koefisien korelasi) sebesar 0,680 artinya variabel rekruitmen $\left(\mathrm{X}_{1}\right)$ dan seleksi $\left(\mathrm{X}_{2}\right)$ mempunyai tingkat pengaruh atau hubungan yang kuat terhadap kinerja karyawan $(\mathrm{Y})$.

c. Analisis Koefisien Determinasi (R Square).

Analisis koefisien determinasi dimaksudkan untuk mengetahui persentase kekuatan hubungan antara variabel independen terhadap variabel dependen baik secara parsial maupun simultan), dalam penelitian ini adalah variabel rekruitmen $\left(\mathrm{X}_{1}\right)$ dan seleksi $\left(\mathrm{X}_{2}\right)$ terhadap kinerja 
karyawan (Y). Berikut ini hasil perhitungan koefisien determinasi yang diolah dengan program SPSS versi 22 , terlihat pada tabel bawah ini:

Tabel 4.22

Hasil Analisis Koefisien

Determinasi Secara Parsial Antara Variabel

Rekruitmen $\left(\mathrm{X}_{1}\right)$ Terhadap

Kinerja Karyawan (Y)

Model Summary

\begin{tabular}{|l|c|c|c|c|}
\hline $\begin{array}{l}\text { Mod } \\
\text { el }\end{array}$ & $\mathrm{R}$ & $\begin{array}{c}\mathrm{R} \\
\text { Squa } \\
\mathrm{re}\end{array}$ & $\begin{array}{c}\text { Adjust } \\
\text { ed R } \\
\text { Squar } \\
\mathrm{e}\end{array}$ & $\begin{array}{c}\text { Std. } \\
\text { Error } \\
\text { of the } \\
\text { Estim } \\
\text { ate }\end{array}$ \\
\hline 1 & $\begin{array}{r}.52 \\
9^{\mathrm{a}}\end{array}$ & .280 & .269 & 3.387 \\
\hline
\end{tabular}

a. Predictors: (Constant), Rekruitmen (X1) n Sumber : Data Primer diolah.

Berdasarkan tabel di atas, diperoleh nilai $R$-square (koefisien determinasi) sebesar 0,280 maka dapat disimpulkan bahwa variabel rekruitmen $\left(\mathrm{X}_{1}\right)$ berpengaruh terhadap variabel kinerja karyawan (Y) sebesar 28\% sedangkan sisanya sebesar $72 \%$ dipengaruhi oleh faktor lain.

Tabel 4.23

Hasil Analisis Koefisien

Determinasi Secara Parsial

Antara VariabelSeleksi $\left(\mathrm{X}_{2}\right)$

Terhadap Kinerja Karyawan (Y)

Model Summary

\begin{tabular}{|l|c|c|c|c|}
\hline $\begin{array}{l}\text { Mod } \\
\text { el }\end{array}$ & $\mathrm{R}$ & $\begin{array}{c}\mathrm{R} \\
\text { Squa } \\
\text { re }\end{array}$ & $\begin{array}{c}\text { Adjust } \\
\text { ed R } \\
\text { Squar } \\
\mathrm{e}\end{array}$ & $\begin{array}{c}\text { Std. } \\
\text { Error } \\
\text { of the } \\
\text { Estim } \\
\text { ate }\end{array}$ \\
\hline 1 & $\begin{array}{c}.64 \\
4^{\mathrm{a}}\end{array}$ & .415 & .406 & 3.053 \\
\hline
\end{tabular}

a. Predictors: (Constant), Seleksi (X2)

n Sumber : Data Primer diolah.

Berdasarkan tabel di atas, diperoleh nilai $R$-square sebesar 0,415 maka dapat disimpulkan bahwa variabel seleksi $\left(\mathrm{X}_{2}\right)$ berpengaruh terhadap variabel kinerja karyawan (Y) sebesar 41,5\% sedangkan sisanya sebesar $58,5 \%$ dipengaruhi oleh faktor lain.

Tabel 4.24

Hasil Analisis Koefisien

Determinasi Secara Simultan

Antara Variabel Rekruitmen $\left(X_{1}\right)$ dan Seleksi $\left(\mathrm{X}_{2}\right)$ Terhadap

Kinerja Karyawan (Y) Model Summary

\begin{tabular}{|l|c|c|c|c|}
\hline $\begin{array}{l}\text { Mod } \\
\text { el }\end{array}$ & $\mathrm{R}$ & $\begin{array}{c}\mathrm{R} \\
\text { Squa } \\
\text { re }\end{array}$ & $\begin{array}{c}\text { Adjust } \\
\text { ed R } \\
\text { Squar } \\
\mathrm{e}\end{array}$ & $\begin{array}{c}\text { Std. } \\
\text { Error } \\
\text { of the } \\
\text { Estim } \\
\text { ate }\end{array}$ \\
\hline 1 & $\begin{array}{r}.68 \\
0^{\mathrm{a}}\end{array}$ & .462 & .446 & 2.949 \\
\hline
\end{tabular}

a. Predictors: (Constant), Seleksi (X2),

Rekruitmen (X1)

n Sumber : Data Primer diolah.

Berdasarkan tabel di atas, diperoleh nilai $R$-square sebesar 0,462 maka dapat disimpulkan bahwa variabel rekruitmen $\left(\mathrm{X}_{1}\right)$ dan seleksi $\left(\mathrm{X}_{2}\right)$ secara simultan berpengaruh terhadap variabel kinerja karyawan (Y) sebesar 46,2\% sedangkan sisanya sebesar $53,8 \%$ dipengaruhi oleh faktor lain yang tidak dilakukan penelitian.

\section{d. Pengujian Hipotesis.}

1) Pengujian Hipotesis Secara Parsial (Uji t).

Untuk pengujian hipotesis variabel rekruitmen $\left(\mathrm{X}_{1}\right)$ dan seleksi $\left(\mathrm{X}_{2}\right)$ terhadap kinerja karyawan $(\mathrm{Y})$ dilakukan dengan uji statistik t (uji secara parsial). Dalam penelitian ini digunakan kriteria signifikansi 5\% $(0,05)$ dengan membandingkan $t_{\text {hitung }}$ dengan $t_{\text {tabel }}$ yaitu sebagai berikut :

(a) Jika $t_{\text {hitung }}<t_{\text {tabel }}:$ berarti $\mathrm{H}_{0}$ diterima dan $\mathrm{H}_{1}$ ditolak

(b) Jika $t_{\text {hitung }}>t_{\text {tabel }} \quad$ : berarti $\mathrm{H}_{0}$ ditolak dan $\mathrm{H}_{1}$ diterima 
Adapun untuk menentukan besarnya $t$ tabel dicari dengan menggunakan rumus berikut ini :

$t_{\text {tabel }}=\mathrm{t} \alpha . \mathrm{df}$ (Taraf Alpha $\times$ Degree of Freedom)

$\alpha \quad=$ tarif nyata $5 \%$

df $=(n-2)$, diperoleh $(69-2)=$

$67, t_{\text {tabel }}(=\mathrm{TINV}, 0.05,67)=1,996$

Dikatakan signifikan jika nilai $t$ hitung $>t_{\text {tabel }}$ atau $\rho$ value $<$ Sig. 0,05 .

(a) Pengaruh Rekruitmen $\left(\mathbf{X}_{1}\right)$ Terhadap Kinerja Karyawan (Y)

Menentukan rumusan hipotesisnya adalah :

$\mathrm{H}_{0}: \rho_{1}=0 \quad$ Tidak terdapat pengaruh positif dan signifikan antara rekruitmen terhadap kinerja karyawan secara parsial pada PT. Boga Lestari Sentosa.

$\mathrm{H}_{1}: \rho_{1} \neq 0$ Terdapat pengaruh positif dan signifikan antara rekruitmen terhadap kinerja karyawan secara parsial pada PT. Boga Lestari Sentosa.

Adapun hasil pengolahan data menggunakan program SPSS Versi 22, dengan hasil sebagai berikut :

Tabel 4.25

\section{Hasil Uji t Variabel Rekruitmen} $\left(\mathrm{X}_{1}\right)$ Terhadap

Kinerja Karyawan (Y) Coefficients $^{a}$

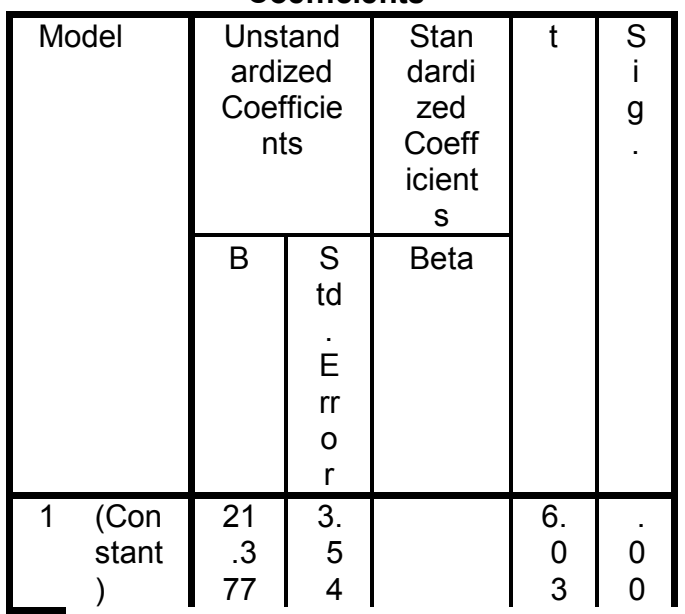

\begin{tabular}{|l|r|r|l|r|l|}
\hline Rekr & & 3 & & 4 & 0 \\
uitm & .4 & .0 & & 5. &. \\
en & 65 & 9 & .529 & 0 & 0 \\
(X1) & & 1 & & 9 & 0 \\
\hline
\end{tabular}

a. Dependent Variable: Kinerja karyawan (Y)

$$
\begin{aligned}
& \text { Sumber : Data Primer } \\
& \text { diolah. }
\end{aligned}
$$

Berdasarkan tabel di atas diperoleh nilai $t$ hitung $>t$ tabel atau $(5,098>1,996)$ Hal tersebut juga diperkuat dengan nilai $\rho$ value $<$ Sig. 0,05 atau $(0,000<0,05)$. Dengan demikian maka $\mathrm{H}_{0}$ ditolak dan $\mathrm{H}_{1}$ diterima, hal ini menunjukkan bahwa terdapat pengaruh yang positif dan signifikan secara parsial antara rekruitmen terhadap kinerja karyawan pada PT. Boga Lestari Sentosa.

\section{(b)Pengaruh Seleksi $\left(\mathbf{X}_{2}\right)$ Terhadap Kinerja Karyawan (Y)}

Menentukan rumusan hipotesisnya adalah :

$\mathrm{H}_{0}: \rho_{2}=0 \quad$ Tidak terdapat pengaruh positif dan signifikan antara seleksi terhadap kinerja karyawan secara parsial PT. Boga Lestari Sentosa.

$\mathrm{H}_{1}: \rho_{2} \neq 0$ Terdapat pengaruh positif dan signifikan antara seleksi terhadap kinerja karyawan secara parsial PT. Boga Lestari Sentosa.

Adapun hasil pengolahan datamenggunakan program SPSS Versi 22, dengan hasil sebagai berikut :

Tabel 4.26

Hasil Uji t Variabel Seleksi $\left(\mathbf{X}_{2}\right)$ Terhadap Kinerja Karyawan (Y)

\begin{tabular}{|c|c|c|c|c|}
\hline Model & $\begin{array}{c}\text { Unstand } \\
\text { ardized } \\
\text { Coefficie } \\
\text { nts }\end{array}$ & $\begin{array}{c}\text { Stan } \\
\text { dardi } \\
\text { zed } \\
\text { Coeff } \\
\text { icient }\end{array}$ & $t$ & $\begin{array}{l}\mathrm{S} \\
\mathrm{i} \\
\mathrm{g} \\
\text {. }\end{array}$ \\
\hline
\end{tabular}
Coefficients $^{\mathrm{a}}$ 


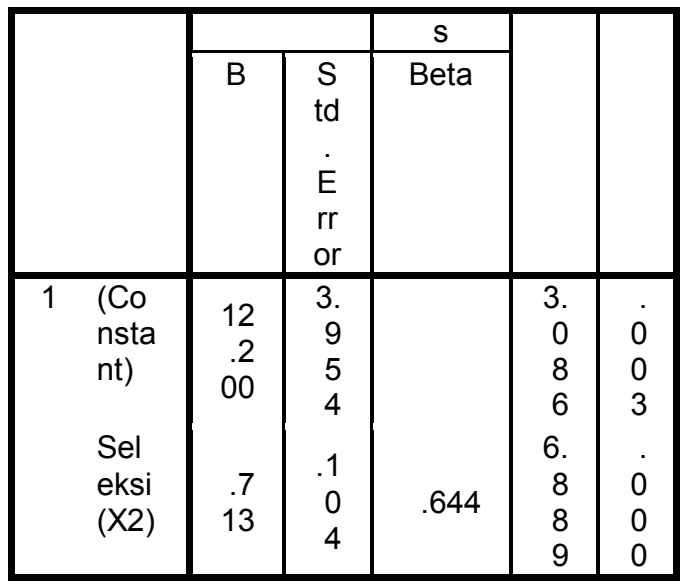

a. Dependent Variable: Kinerja karyawan (Y)

Sumber : Data Primer diolah.

Berdasarkan tabel di atas diperoleh nilai $t$ hitung $>t$ tabel atau $(6,889>1,996)$ Hal tersebut juga diperkuat dengan nilai $\rho$ value $<$ Sig.0,05 atau $(0,000<0,05)$. Dengan demikian maka $\mathrm{H}_{0}$ ditolak dan $\mathrm{H}_{2}$ diterima, hal ini menunjukkan bahwa terdapat pengaruh yang positif dan signifikan secara parsial antara seleksi terhadap kinerja karyawan pada PT. Boga Lestari Sentosa.

2) Pengujian Hipotesis Secara Simultan (Uji F).

Untuk pengujian pengaruh variabel independen terhadap variabel dependen secara simultan dilakukan dengan uji statistik $F$ dengan signifikansi 5\% dengan membandingkan antara nilai $F$ hitung dengan $F$ tabel dengan ketentuan sebagai berikut :

(a) Jika $F_{\text {hitung }}<F_{\text {tabel }}$ : berarti $\mathrm{H}_{0}$ diterima dan $\mathrm{H}_{3}$ ditolak

(b) Jika $F_{\text {hitung }}>F_{\text {tabel }}$ : berarti $\mathrm{H}_{0}$ ditolak dan $\mathrm{H}_{3}$ diterima

Untuk menentukan besarnya $F_{\text {tabel }}$ dicari dengan ketentuan $\mathrm{df}=(\mathrm{n}-\mathrm{k}-1)$, maka diperoleh $(69-2-1)=66$, jadi $F_{\text {tabel }}=2,740$
Dikatakan signifikan jika nilai $F$ hitung $>\mathrm{F}_{\text {tabel }}$ atau $\rho$ value $<$ Sig. 0,05 .

Rumusan hipotesisnya adalah sebagai berikut :

$\mathrm{H}_{0}: \rho_{1,2}=0 \quad$ Tidak terdapat pengaruh positif dan signifikan secara simultan antara rekruitmen dan seleksi terhadap kinerja karyawan pada PT. Boga Lestari Sentosa.

$\mathrm{H}_{3}: \rho_{1,2} \neq 0$ Terdapat pengaruh positif dan signifikan secara simultan antara rekruitmen dan seleksi terhadap kinerja karyawan pada PT. Boga Lestari Sentosa.

Tabel 4.27

Hasil Hipotesis (Uji F) Simultan

Variabel Rekruitmen $\left(X_{1}\right)$ dan

Seleksi $\left(\mathrm{X}_{2}\right)$ Terhadap Kinerja Karyawan (Y)

ANOVA $^{a}$

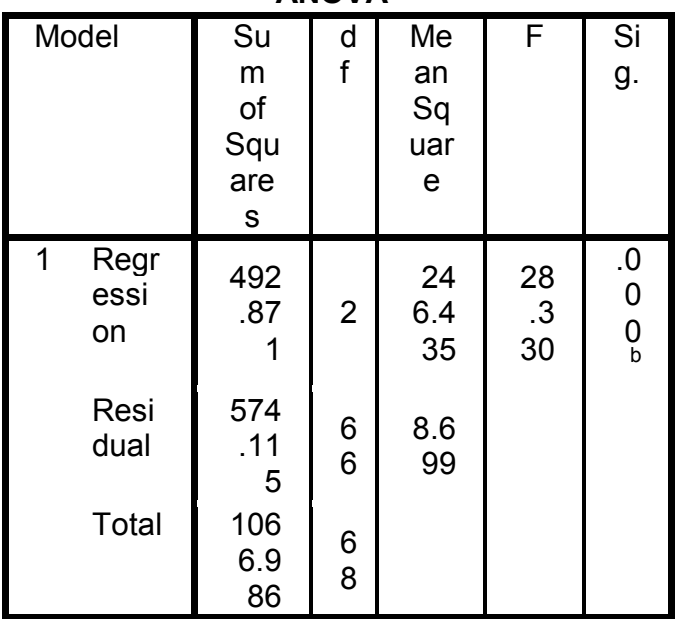

a. Dependent Variable: Kinerja Karyawan (Y)

b. Predictors: (Constant), Seleksi (X2),

Rekruitmen (X1)

Sumber : Data Primerdiolah.

Berdasarkan tabel di atas diperoleh nilai $F_{\text {hitung }}>\quad \mathrm{F}_{\text {tabel }}$ atau $(28,330>2,740)$, hal ini juga diperkuat dengan $\rho$ value $<$ Sig.0,05 atau $(0,000<0,05)$. Dengan demikian maka $\mathrm{H}_{0}$ ditolak dan $\mathrm{H}_{3}$ diterima, hal ini menunjukkan bahwa terdapat pengaruh yang positif dan 
signifikan secara simultan antara rekruitmen dan seleksi terhadap kinerja karyawan pada PT. Boga Lestari Sentosa.

\section{E. Pembahasan Hasil Penelitian 1. Pembahasan Deskriptif.}

Pembahasan deskriptif, dimaksudkan untuk eksplorasi dan klarifikasi mengenai suatu fenomena atau kenyataan sosial, dengan jalan mendeskripsikan sejumlah variabel yang berkenaan dengan masalah yang diteliti.

a. Keadaan atau kriteria obyek yang diteliti berdasar pada variabel rekruitmen $\left(\mathrm{X}_{1}\right)$.

Secara keseluruhan untuk kuesioner variabel rekruitmen $\left(\mathrm{X}_{1}\right)$ diperoleh rata-rata score 3.86 dengan kriteria baik. Dari ketiga indikator tersebut yang mendapatkan rattingscore yang paling rendah adalah indikator metode penarikan dimana hanya mencapai score 3,71 meskipun termasuk dalam kategori baik namun mengingat rekrutmen merupakan salah satu fungsi manajemen sumber daya manusia (MSDM) pada aspek pengadaan tenaga kerja yang khusus mendapatkan calon-calon karyawan untuk kemudian diseleksi mana yang paling baik dan paling sesuai dengan persyaratan yang diperlukan,

Salah satunya adalah melalui metode rekrutmen yang baik dengan melibatkan manajer departemen terkait yang membutuhkan penambahan tenaga kerja sehingga tidak hanya menjadi tugas dan tanggung jawab utama dari departemen sumber daya manusia (SDM) karena kualitas sumber daya manusia perusahaan juga tergantung pada kualitas suatu proses rekrutmennya.

b. Keadaan atau kriteria obyek yang diteliti berdasar pada variabel Seleksi $\left(\mathrm{X}_{2}\right)$.

Secara keseluruhan untuk kuesioner variabel seleksi $\left(\mathrm{X}_{2}\right)$ diperoleh rata-rata score 3.80 dengan kriteria baik.

Dari kelima indikator tersebut yang mendapatkan ratting score yang paling rendah adalah indikator umur dimana hanya mencapai score 3,64 meskipun termasuk dalam kategori baik namun mengingat seleksi merupakan proses dalam menentukan pilihan calon karyawan yang sesuai dengan kriteria yang dipersyaratkan, faktor usia harus diperhatikan agar tidak melanggar ketentuan yang berlaku serta juga mempertimbangkan keahlian, pengalaman calon karyawan.

c. Keadaan atau kriteria obyek yang diteliti berdasar pada variabel Kinerja Karyawan (Y).

Secara keseluruhan untuk kuesioner variabel kinerja karyawan (Y) diperoleh rata-rata score 3.98 dengan kriteria baik. Dari kelima indikator tersebut yang mendapatkan rattingscore yang paling rendah adalah indikator kualitas kerja dimana hanya mencapai score 3,68 meskipun termasuk dalam kategori baik namun mengingat kualitas kerja menjadi faktor penting dalam mengukur keberhasilan perusahaan maka kinerja harus menggambarkan kualitas.

Kualitas kerja yang baik terukur dan sesuai persepsi karyawa terhadap kualitas pekerjaan yang dihasilkan serta kesempurnaan tugas terhadap 
keterampilan dan kemampuan karyawan serta pengukuran kinerja karyawan harus mampu menerapkan suatu sistem manajemen kinerja. Penilaiannya disesuaikan dengan nilai kerja karyawan yang diperoleh dari satu tahun berjalan.

\section{Pembahasan Verifikatif}

Pembahasan verifikatif dimaksudkan untuk membahas perihal pengaruh dan signifikansinya serta, pembahasan keterkaitan teori yang mendukung yang diselaraskan dengan hasil pengolahan data.

\section{a. Pengaruh Rekruitmen $\left(\mathbf{X}_{1}\right)$}

Terhadap Kinerja Karyawan (Y).

Berdasarkan hasil statistik, diperoleh nilai $R$ (koefisien korelasi) sebesar 0,529 artinya variabel rekruitmen $\left(\mathrm{X}_{1}\right)$ terhadap kinerja karyawan (Y) mempunyai tingkat pengaruh yang sedang dengan kontribusi pengaruh sebesar 0,280 atau $28 \%$ sedangkan sisanya $72 \%$ dipengaruhi oleh faktor lain. Hal ini menunjukkan bahwa rekruitmen yang tepat akan meningkatkan kinerja karyawan. Dari pengujian hipotesis diperoleh $t_{\text {hitung }}>t_{\text {tabel }}$ atau $(5,098>1,996)$ hal itu juga dibuktikan dengan signifikansi 0,000 $<0,05$. Dengan demikian maka $\mathrm{H}_{0}$ ditolak dan $\mathrm{H}_{1}$ diterima, hal ini menunjukkan bahwa terdapat pengaruh yang positif dan signifikan secara parsial antara rekruitmen terhadap kinerja karyawan pada PT. Boga Lestari Sentosa.

Hal ini menunjukkan bahwa pelaksanaan rekrutmen khususnya PT Boga Lestari Sentosa berdampak terhadap kinerja karyawan, dimana semakin baik rekrutmen maka dampaknya terhadap kinerja karyawan akan dapat lebih ditingkatkan.

\section{b. Pengaruh Seleksi $\left(\mathbf{X}_{2}\right)$ Terhadap Kinerja Karyawan (Y)}

Berdasarkan hasil statistik, diperoleh nilai $R$ (koefisien korelasi) sebesar 0,644 artinya variabel seleksi $\left(\mathrm{X}_{2}\right)$ terhadap kinerja karyawan $(\mathrm{Y})$ mempunyai tingkat pengaruh yang kuat dengan kontribusi pengaruh sebesar 0,415 atau 41,5 sedangkan sisanya $58,5 \%$ dipengaruhi oleh faktor lain. Hal ini menunjukkan bahwa seleksi yang tepat akan meningkatkan kinerja karyawan. Dari pengujian hipotesis diperoleh $t_{\text {hitung }}>t_{\text {tabel }}$ atau $(6,889>1,996)$ hal itu juga dibuktikan dengan signifikansi $0,000<0,05$. Dengan demikian maka $\mathrm{H}_{0}$ ditolak dan $\mathrm{H}_{2}$ diterima, hal ini menunjukkan bahwa terdapat pengaruh yang positif dan signifikan secara parsial antara seleksi terhadap kinerja karyawan pada PT. Boga Lestari Sentosa.

Hal ini menunjukkan bahwa pelaksanaan seleksi berdampak terhadap kinerja karyawan, dimana seleksi dapat diikuti oleh peningkatan kinerja karyawan.

c. Pengaruh Rekruitmen $\left(X_{1}\right)$ dan

Seleksi $\left(\mathbf{X}_{2}\right)$ Terhadap Kinerja Karyawan (Y).

Berdasarkan hasil penelitian, menunjukkan bahwa rekruitmen $\left(\mathrm{X}_{1}\right)$ dan seleksi $\left(\mathrm{X}_{2}\right)$ berpengaruh positif terhadap kinerja karyawan pada PT. Boga Lestari Sentosa dengan diperoleh persamaan regresi $\mathrm{Y}=$ $9,271+0,227 \mathrm{X}_{1}+0,560 \mathrm{X}_{2}$. Hasil analisis regresi ini menunjukkan koefisien dari masing-masing variabel bertanda positif, artinya semakin baik rekruitmen dan seleksi maka akan semakin baik pula kinerja 
karyawan pada PT. Boga Lestari Sentosa, sebaliknya semakin rendah rekruitmen dan seleksi maka akan semakin rendah pula kinerja karyawan. Sedangkan tingkat hubungannya atau pengaruh antara variabel bebas dengan variabel terikat diperoleh sebesar 0,680 artinya memiliki memiliki hubungan atau pengaruh yang kuat. Kontribusi pengaruh rekruitmen dan seleksi adalah sebesar 46,2\% sedangkan sisanya sebesar 53,8\% dipengaruhi oleh faktor lain. Pengujian hipotesis diperoleh $\quad F_{\text {hitung }}>F_{\text {tabel }}$ atau $(28,330$ $>2,740$ ), hal tersebut juga diperkuat dengan probability $0,000<0,05$.

Dengan demikian $\mathrm{H}_{0}$ ditolak dan $\mathrm{H}_{3}$ diterima. Artinya terdapat pengaruh positif dan signifikan secara simultan antara rekruitmen dan seleksi terhadap kinerja karyawan pada PT. Boga Lestari Sentosa.

\section{PENUTUP}

\section{Kesimpulan}

Berdasarkan uraian pada babbabsebelumnya, dan dari hasila nalisis serta pembahasan mengenai pengaruh rekrutmen dan seleksi terhadap kinerja karyawan, sebagai berikut :

1. Rekrutmen berpengaruh positif dan signifikan terhadap kinerja karyawan dengan nilai koefisien korelasi sebesar 0,529 artinya memiliki hubungan atau pengaruh yang sedang dengan kontribusi pengaruh sebesar 28\%. Uji hipotesis diperoleh $t_{\text {hitung }}>t_{\text {tabel }}$ atau $(5,098>1,996)$, hal ini diperkuat dengan probability $0,000<0,05$, dengan demikian $\mathrm{H}_{0}$ ditolak dan $\mathrm{H}_{1}$ diterima artinya terdapat pengaruh yang positif dan signifikan antara rekrutmen terhadap kinerja karyawan pada PT. Boga Lestari Sentosa.

2. Seleksi berpengaruh positif dan signifikan terhadap kinerja karyawan dengan nilai koefisien korelasi sebesar 0,644 artinya memiliki hubungan atau pengaruh yang kuat dengan kontribusi pengaruh sebesar $41,5 \%$. Uji hipotesis diperoleh $t_{\text {hitung }}>t_{\text {tabel }}$ atau $(6,889>1,996)$, hal ini diperkuat dengan probability $0,000<0,05$, dengan demikian $\mathrm{H}_{0}$ ditolak dan $\mathrm{H}_{2}$ diterima artinya terdapat pengaruh yang positif dan signifikan antara seleksi terhadap kinerja karyawan pada PT. Boga Lestari Sentosa.

3. Rekrutmen dan seleksi berpengaruh positif dan signifikan terhadap kinerja karyawan dengan persamaa nregresi $\mathrm{Y}=9,271+$ $0,227 \mathrm{X}_{1}+0,560 \mathrm{X}_{2}$. Semakin baik rekrutmen dan seleksi maka kinerja karyawan juga akan semakin meningkat. Nilai korelasi atau tingkat hubungannya antara variable bebas dengan variable terikat diperoleh sebesar 0,680 artinya memiliki hubungan atau pengaruh yang kuat dengan kontribusi pengaruh secara simultan sebesar $46,2 \%$ sedangkan sisanya sebesar $53,8 \%$ dipengaruhi faktor lain. Uji hipotesis diperoleh nilai $F_{\text {hitung }}>F_{\text {tabel }}$ atau $(28,330>$ 2,740 ), hal tersebut juga diperkuat dengan probability $0,000<0,05$. Dengan demikian $\mathrm{H}_{0}$ ditolak dan $\mathrm{H}_{3}$ diterima. Artinya terdapat pengaruh positif dan signifikan secara simultan antara rekrutmen dan seleksi terhadap kinerja 
karyawanpada PT. Boga Lestari Sentosa.

\section{Saran}

Berdasarkan hasil penelitiandan pembahasan yang telah dilakukan peneliti, maka peneliti dapat memberikan saran sebagaiberikut :

1. Variabel rekrutmen, indikator yang paling lemah ada pada metode penarikan dimana hanya mencapai score 3,71 meskipun termasuk dalam kategori baik namun mengingat rekrutmen merupakan salah satu fungsi manajemen sumber daya manusia (MSDM) pada aspek pengadaan tenaga kerja yang khusus mendapatkan calon-calon karyawan untuk kemudian diseleksi mana yang paling baik dan paling sesuai dengan persyaratan yang diperlukan, salah satunya adalah melalui metode rekrutmen yang baik dengan melibatkan manajer departemen terkait yang membutuhkan penambahan tenaga kerja sehingga tidak hanya menjadi tugas dan tanggungjawab utama dari departemen sumber daya manusia (SDM) karena kualitas sumber daya manusia perusahaan juga tergantung pada kualitas suatu proses rekrutmen.

2. Variabel seleksi, indikator yang paling lemah adalah indicator umur dimana hanya mencapai score 3,64 meskipun termasuk dalam kategori baik namun mengingat seleksi merupakan proses dalam menentukan pilihan calon karyawan yang sesuai dengan kriteria yang dipersyaratkan, factor usia harus diperhatikan agar tidak melanggar ketentuan yang berlaku serta juga mempertimbangkan keahlian, pengalaman calon karyawan.

3. Variabel kinerja karyawan, indikator yang paling lemah adalah indicatorkualitas kerja dimana hanya mencapai score 3,68 meskipun termasuk dalam kategori baik namun mengingat kualitas kerja menjadi factor penting dalam mengukur keberhasilan perusahaan maka kinerja harus menggambarkan kualitas. Kualitas kerja yang baik terukur dan sesuai persepsi karyawan terhadap kualitas pekerjaan yang dihasilkan serta kesempurnaan tugas terhadap keterampilan dan kemampuan karyawan serta pengukuran kinerja karyawan harus mampu menerapkan suatu system manajemen kinerja. Penilaiannya disesuaikan dengan nilai kerja karyawan yang diperoleh dari satu tahun berjalan.

4. Kontribusi pengaruh rekrutmen dan seleksi secara simultan terhadap kinerja karyawan sebesar $46,2 \%$, nilai ini masih bisa ditingkatkan dengan secara selektif dapat memprioritaskan kebutuhan penerimaan karyawan dan benar-benar sesuai dengan kebutuhan dan kualifikasi yang dibutuhkan dan kondisi masingmasing variable bebas harus ditingkatkan secara signifikan. Oleh karenanya disarankan kepada penelitian berikutnya agar melakukan penelitian yang relevan dengan cara memperbaiki indikator yang masih tidak baik atau dengan menambah indicator peryataan dan jumlah responden penelitian sehingga akan dapat 
lebih diketahui variabel yang paling memberikan kontribusi positif bagi perusahaan.

\section{DAFTAR PUSTAKA}

A.A. Anwar Prabu Mangkunegara (2013), Manajamen Sumber Daya Manusia Perusahaan, PT Remaja Rosdakarya, Bandung.

Akdon, Riduwan (2012), Rumus dan Data Dalam Aplikasi Statistika. Cetakan I. Bandung: Alfabeta

Hasibuan, Malayu SP (2011), Manajemen Sumber Daya Manusia, Edisi Revisi, Penerbit Bumi Aksara, Jakarta.

Henry Simamora (2005), Manajemen Sumber Daya Manusia, STIE YKPN Bandung.

Malthis. L.Robert dan Jackson. H. John (2011), Manajemen Sumber Daya Manusia, Jakarta : Buku Kedua.

Marwansyah (2012), Manajemen Sumber Daya Manusia, Alfabeta. Jakarta.

Moekijat (2010), Manajemen Sumber Daya Manusia, Bandung: CV Mandar Maju.

Nawawi, Hadari, (2012), Manajemen Sumber Daya Manusia Untuk Bisnis Yang Kompetitif, Gajah Mada University Press, Yogyakarta.

Rivai,Veithzal (20011), Manajemen Sumber Daya Manusia Untuk Perusahaan Dari Teori ke
Praktik, Jakarta: Rajawali Press.

Robbins, Stephen P (2001), Perilaku Organisasi, Salemba Empat, Jakarta.

Sedarmayanti (2011), Manajemen Sumber Daya Manusia, CV. Mandar Maju, Jakarta.

Siagian, Sondong. P. (2015), Manajemen Sumber Daya Manusia, PT Rineka

Cipta. Jakarta.

Sinambela, Poltak (2012), Manajemen Sumber Daya Manusia, Bumi Aksara. Jakarta.

Siswanto (2011), Manajemen Tenaga Kerja Indonesia, Bumi Aksara. Jakarta.

Sunyoto (2015), Manajemen Sumber Daya Manusia, Bumi Aksara.. Jakarta.

Sugiyono (2016), Metode Penelitian Administrasi : dilengkapi dengan Metode $R$ $\& D$, , Alfabeta, Bandung.

SuharsimiArikunto (2006), Manajemen Penelitian, Edisi Revisi, Cetakan Ketujuh, Rineka Cipta, Jakarta.

Surakhmad Winarno (2005), Pengantar Penelitian Ilmiah, Tarsito, Bandung.

T. Hani Handoko (2008), Manajemen Personalia dan 
Sumber Daya Manusia, Cetakan KeempatbelasYogyakarta:

\section{BPFE}

Umar, Husein (2008), Riset Sumber Daya Manusia, Cetakan Keenam, Jakarta: Gramedia Pustaka Utama.
Wilson, Bangun J.B. (2011), Manajemen Sumber Daya Manusia, Erlangga. Jakarta.

Wirawan (2012), Manajemen Sumber Daya Manusia, Salemba Empat. Jakarta. 